\title{
Permanent tracheostomy in a horse: a case report
}

\author{
Traqueostomia permanente em equino: relato de caso \\ Jéssica Monique dos Santos Lima (1), Bismark Alves da Silva² (1), Edson Teixeira Pereira ${ }^{3}$ (1), \\ Alex Carlos da Silva França ${ }^{4}$ (D) , Heider Irinaldo Pereira Ferreira 5 (i), Ana Luiza Cordeiro Gondim Guimarães ${ }^{6 *}$ (1)
}

\begin{abstract}
Problems related to the locomotor and gastrointestinal systems correspond to the highest percentage of clinical cases. However, diseases related to the respiratory system can result in low animal performance or even the animal's removal from athletic life. This paper aims to report a case of permanent tracheotomy in a horse. The animal was treated at the Jerônimo Dix-Huit Rosado Maia Veterinary Hospital - HOVET, with respiratory noise and dyspnea claims. In the anamnesis, the owner reported that the animal had been presenting respiratory difficulty for 20 days. On physical examination, respiratory noise and dyspnea were noted. Endoscopy was performed, from which a marked decrease in the arytenoid cartilage movement on the right and left sides was noted. It was possible to diagnose a stage IV case of bilateral laryngeal hemiplegia, combining clinical signs with endoscopy findings. Thus, the surgical treatment of permanent tracheostomy was chosen. After surgery, drug therapy using antibiotics and anti-inflammatory drugs was performed. In addition, a $n^{\circ} 6$ metal tracheostomy cannula was inserted. After 36 days of hospitalization, the animal was discharged with regression of clinical signs.
\end{abstract}

KEYWORDS: Laryngeal hemiplegia; arytenoid cartilage; endoscopy; equine culture.

RESUMO: Problemas relacionados aos sistemas locomotor e gastrointestinal correspondem ao maior percentual de casos clínicos. No entanto, doenças relacionadas ao sistema respiratório podem resultar em baixo desempenho do animal ou mesmo na retirada do animal da vida atlética. Este trabalho tem como objetivo relatar um caso de traqueotomia permanente em um cavalo. O animal foi atendido no Hospital Veterinário Jerônimo Dix-Huit Rosado Maia - HOVET, com queixas de ruído respiratório e dispneia. $\mathrm{Na}$ anamnese, o proprietário relatou que o animal apresentava dificuldade respiratória há 20 dias. Ao exame físico, notou-se ruído respiratório e dispneia. Foi realizada endoscopia, a partir da qual foi notada diminuiçáo acentuada do movimento da cartilagem aritenoide nos lados direito e esquerdo. Foi possível diagnosticar um caso em estágio IV de hemiplegia laríngea bilateral, combinando os sinais clínicos com os achados endoscópicos. Assim, optou-se pelo tratamento cirúrgico da traqueostomia definitiva. Após a cirurgia, foi realizada terapia medicamentosa com antibióticos e anti-inflamatórios. Além disso, uma cânula de traqueostomia de metal no 6 foi inserida. Após 36 dias de internação, o animal recebeu alta com regressão dos sinais clínicos.

PALAVRAS-CHAVE: hemiplegia laríngea; cartilagem aritenoide; endoscopia; equinocultura.

\section{INTRODUCTION}

Despite the high number of equine breeders and the growing search for specialized professionals, several diseases still lead to economic losses, primarily gastrointestinal, locomotor, and respiratory disorders. Regarding the respiratory system, there are emergencies where the animal presents evident clinical signs at rest, such as effort and respiratory noise, in addition to dorsal decubitus as asphyxia progresses. In these cases, the professional must be attentive to a fast and efficient approach, minimizing the risks to the animal's life (BYRNE \& BARAKZAI, 2020).
Idiopathic laryngeal hemiplegia can occur due to degeneration of the recurrent laryngeal nerve, mycosis in the guttural pouch, or by perivascular application of irritating material; however, the leading cause of this disease is still unknown (RADOSTITS et al., 2010). Some research suggests that this disease has a genetic basis, and current data proposes that most respiratory diseases result from several genes and environmental factors. Considering this, some breeders' associations have adopted selection criteria to remove affected animals from breeding and thus reduce the risk of producing more offspring affected by the disease (GERBER, 2020).

\footnotetext{
1Mestranda do Programa de Pós-graduação em Ciência Animal da Universidade Federal Rural do Semi- Árido, Mossoró, Brasil.

${ }^{2}$ Mestrando do Programa de Pós-graduação em Ambiente, Tecnologia e Sociedade da Universidade Federal Rural do Semi- Árido, Mossoró, Brasil.

${ }^{3}$ Médico Veterinário Autônomo, Acopiara, Ceará, Brasil.

${ }^{4}$ Médica Veterinário Autônomo, Arapiraca, Alagoas, Brasil.

${ }^{5}$ Médico Veterinário setor de Grandes animais- Universidade Federal Rural do Semi- Árido, Mossoró, Brasil.

${ }^{\circ}$ Graduanda Medicina Veterinária- Universidade Federal Rural do Semi- Árido, Mossoró, Brasil.

*Corresponding author: luizacordeiro73@gmail.com

Received: 20/02/2021. Accepted: 05/06/2021
} 
Laryngeal hemiplegia is a progressive upper airway dysfunction in horses. Recurrent laryngeal neuropathy is the idiopathic form of laryngeal hemiplegia. It is a degenerative neuropathy of the recurrent laryngeal nerve, with more frequent involvement on the left side, resulting in lesions of the laryngeal muscles. Consequently, horses with this condition suffer from inspiratory stridor and exercise intolerance at higher speeds and workloads. Thus, recurrent laryngeal neuropathy is particularly relevant to sport, work, and race horses, and often leads to surgical intervention, early retirement, or even euthanasia (CLERCQ et al., 2018; GERBER, 2020).

In cases with severe dyspnea caused by laryngeal or pharyngeal obstruction, a tracheostomy may be necessary. Usually, the obstruction can be bypassed by placing a nasotracheal cannula under endoscopic guidance or performing a temporary tracheotomy to ensure a patent airway. After this stabilization, further investigation into the cause of the airway obstruction can be performed. Endoscopy is usually the most valuable diagnostic tool (VALBERG, 2020).

Thus, the objective of this study was to report a case of permanent tracheotomy in a horse, describing the treatment used, as well as the results obtained through the surgical procedure.

\section{CASE REPORT}

A female horse, SRD (No Defined Breed), brown coat, seven years old, from the city of Russas, in the state of Ceará, was seen at the Jerônimo Dix-Huit Rosado Maia Veterinary Hospital - HOVET, at the Federal University of Rural do Semiárido (UFERSA), presenting loud respiratory noise and dyspnea (Figure 1).

During the anamnesis, the owner reported that the animal was kept in a semi-extensive system, i.e., it spent the day outdoors, and at night it was taken to a stall. The food provided was native pasture, and the animal had no history of vaccination and deworming. The owner noticed that the animal had respiratory difficulty for 20 days. Since then, there has been an evolution of clinical signs. Clenbuterol, bromhexine hydrochloride, and benzylpenicillin procaine-based treatments were administered on the property. The period of administration of the drugs was not informed. After the treatment, there was no improvement, and the animal continued to present the same symptoms.

On general physical examination, the animal had a heart rate of $68 \mathrm{bpm}$, respiratory rate of $20 \mathrm{mpm}$, capillary refill time of 2 seconds, pale mucous membranes, normal intestinal motility, stationary attitude, active behavior, and normal appetite. As for the specific physical examination, the patient presented severe dyspnea with "snoring" sounds and dilated nostrils, as shown in Figure 1.

Further examination was requested to confirm the suspicion of hemiplegia since the clinical signs were suggestive of the disease. Thus, endoscopy was performed, with the animal in quadrupedal position, without sedation. No apparent

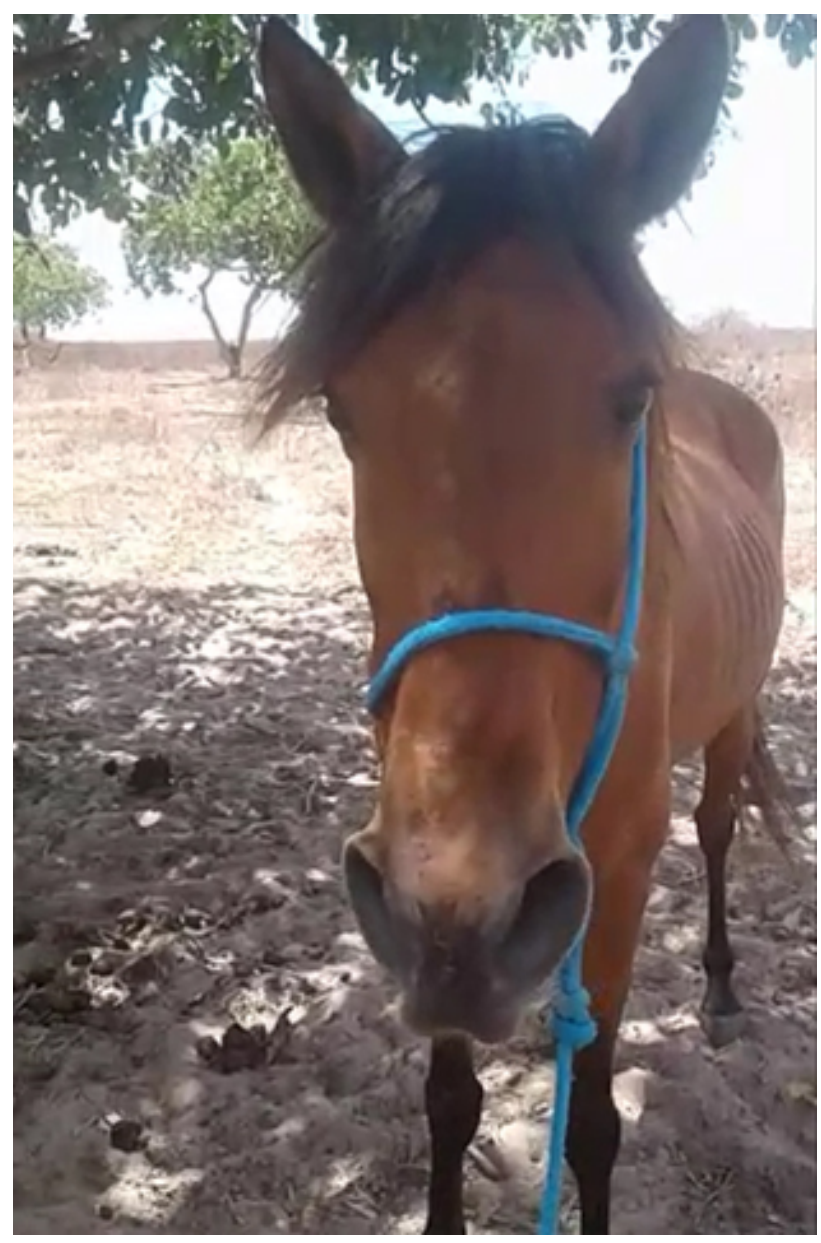

Figure l. Animal with dilated nostrils presenting respiratory distress.

changes were observed in the nasal meatus and ethmoid region. In addition, the arytenoid cartilages did not show adduction and abduction movements on the right and left sides. Based on this, in addition to the clinical signs and endoscopy findings, a case of bilateral laryngeal hemiplegia, stage IV, was diagnosed.

Given the exam results and the history and anamnesis, the case was presented to the owner, who did not have the resources for very costly procedures, besides the fact that the animal had low zootechnical value. Thus, we opted for the surgical treatment of permanent tracheostomy.

Blood count and serum biochemistry were requested as preoperative tests, which presented the following results: 8.0 million $/ \mathrm{mm}^{3}$ of red blood cells content, (Ref. 7-13 million $/ \mathrm{mm}^{3}$ ), 34\% haematocrit (Ref. 32-55\%), $39 \mathrm{fL} \mathrm{MCV}$ (Ref. 37-52 fL), 34\% MCHC (Ref. 31-35\%), 12,100 mm leukocytes (Ref. 5,200-13,900 / mm³), $24 \mathrm{mg} / \mathrm{dL}$ urea (Ref. 21.4-51.3 mg/dL) and $1.6 \mathrm{mg} / \mathrm{dL}$ creatinine (Ref. 1.2$1.9 \mathrm{mg} / \mathrm{dL}$ ). The exams were within the parameters for the species, making it possible to perform the procedure.

On October 24, 2019, the surgical tracheostomy procedure was performed with the animal in the dorsal decubitus position. First, the animal was submitted to sedation with detomidine administered at $0.02 \mathrm{mg} / \mathrm{kg}$, followed by induction of anesthesia with ketamine at $2 \mathrm{mg} / \mathrm{kg}$. Then, intubation 
with a tracheal cannula was performed for maintenance under inhalational anesthesia with isoflurane. Site trichotomy and antisepsis were performed with $2 \%$ degerming iodine and $70 \%$ alcohol, followed by sterile field cloths. A 5-cm-long skin incision was made with a number 4 scalpel and a 24 blade. The sternohyoid muscles were separated with Mayo scissors to expose the proximal cervical trachea with a ventral cervical midline incision. The Gosset retractor was used for better exposure of the cervical trachea. With the help of anatomical tweezers, it was possible to lift the edges of the cartilage where a tunnel was made comprising an area from the third to the sixth tracheal cartilages with a width of $2 \mathrm{~cm}$ forming a rectangular segment. Next, the tracheal mucosa and skin suturing were performed with a different single suture pattern and 2-0 polypropylene unabsorbable thread (Figure 2).

In the postoperative period, penicillin was intramuscularly administered at a dose of 20,000 IU/kg, 48 hours apart, for seven days. Flunixin meglumine at a dose of $1.1 \mathrm{mg} / \mathrm{kg}$, intravenously, once a day, for seven days, and a single intramuscular dose of 5,000 IU antitetanic serum were also administered. In addition, the surgical wound was cleaned with $2 \%$ chlorhexidine, and the dressing was changed daily. The animal was hospitalized for 36 days to perform the drug treatment along with wound cleaning so that it was possible to place the $\mathrm{n}^{\circ} 6$ metal tracheostomy cannula, with $0.12 \mathrm{~mm}$ in diameter (Figure 3). After this period, the animal was fully recovered and discharged from the hospital.

\section{RESULTS AND DISCUSSION}

The main complaint raised by the owner was that the animal had difficulty breathing and loud breathing sounds. According to Lawrence et al. (2018), several conditions can cause dynamic upper airway collapse in equines and lead them to show signs of respiratory distress, decreased performance, and even respiratory noises. These cases are well recognized in horses, explicitly defined by the anatomical structures involved. In addition, it is an important cause for surgical intervention.
The endoscopic examination was performed with the animal in a quadrupedal position, at rest, without the need for sedation. Based on the findings, it was possible to diagnose a stage IV case of bilateral laryngeal hemiplegia. Laryngeal hemiplegia most commonly affects the left arytenoid cartilage, resulting from an idiopathic degeneration of the left recurrent laryngeal nerve. This left nerve is responsible for the paresis of the left arytenoid primary abductor, the dorsal cricoarytenoid muscle (LAWRENCE et al., 2018). Bilateral laryngeal paralysis is rare and can be caused by central nervous system disease, poisoning, general anesthesia, or encephalopathy following liver failure. However, the condition can quickly become lifethreatening, and the prognosis is reserved (DAVENPORTGOODALL \& PARENTE, 2003).

Endoscopy without sedation is crucial because it does not interfere with laryngeal mobility. A careful examination is also needed to evaluate each anatomical structure, paying attention to possible changes in shape, size, and the presence of mass. In addition, the degree of asymmetry of the arytenoid cartilages should be noted. According to Havemeyer's classification adapted from Dixon et al. (2004), the endoscopic classification system of the resting larynx was observed.

After clinical evaluation added to the endoscopy results, the surgical treatment of tracheostomy was chosen. For this

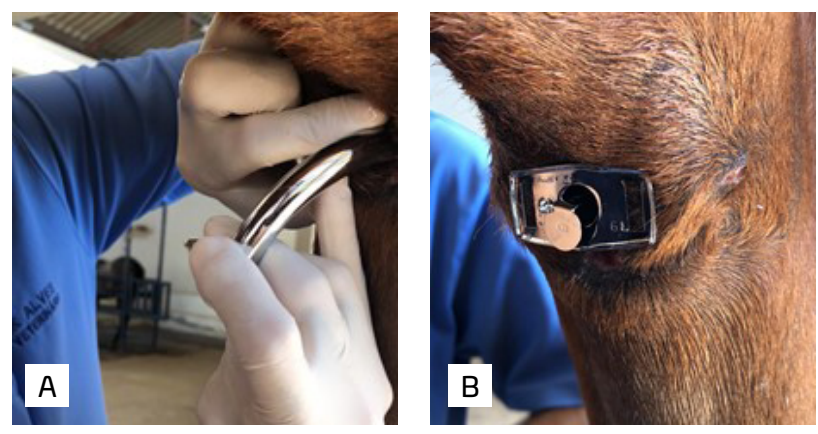

Figure 3. Placement of the tracheostomy cannula. B-Fixed tracheostomy cannula.
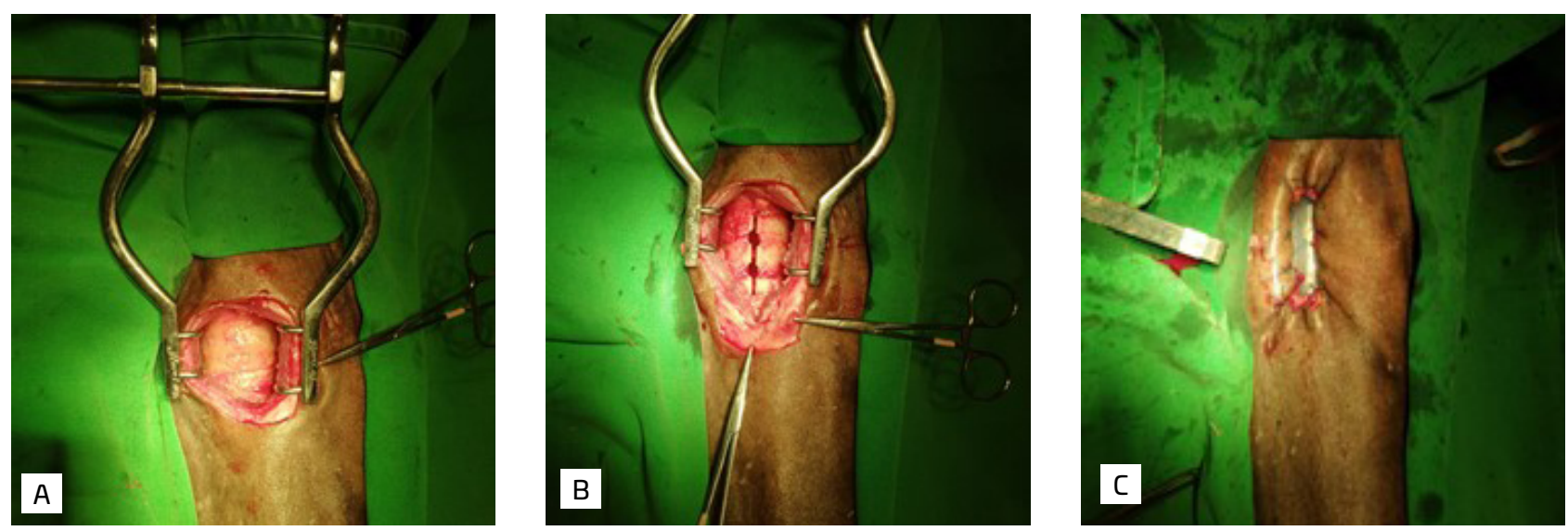

Figure 2. A- Sternotomy-hyoid muscle separation B- Tracheal ring incision C- Skin to mucosa suture 
procedure, Auer (2018) reports that a $10 \mathrm{~cm}$ ventral midline incision is made immediately caudal to the larynx. The sternothyroid muscles are separated and retracted laterally to expose four to five tracheal rings. A ventral midline and two paramedian incisions, $15 \mathrm{~mm}$ on either side of the midline, are made through the tracheal cartilages without rupturing the underlying tracheal mucosa. The rectangular pieces of cartilage are carefully dissected from the tracheal submucosa and removed. The tracheal mucosa and annular ligaments are incised in a double-Y pattern, with the midline incision ending at about a tracheal ring before the rostral and caudal extension of the exposed mucosa. Then, starting with the cranial and caudal ends of the stoma, the mucosa is sutured to the skin in a simple interrupted pattern using 0 or 2-0 polydioxanone or polyglactin 910 suture material.

According to Clercq et al. (2018), other techniques, such as nerve grafting and pacemakers, are being explored and may even be considered as better alternative treatments in the future. In sport horses with idiopathic laryngeal neuropathy without postoperative complications, the prognosis is favorable.

Postoperatively, drug therapy based on penicillin, flunixin meglumine, and 5,000 IU antitetanic serum was instituted. In addition, the surgical wound was cleaned with $2 \%$ chlorhexidine and changed daily for 15 days. During the first 07 days, wound dehiscence was noted. However, it was possible to observe that there was complete healing after the hospitalization period. Ronaldson (2020) reported that the second intention could restore the surgical wound at the tracheostomy site if suture dehiscence occurs (Figure 4).

According to Auer (2018), horses are kept on antimicrobials and NSAIDs for 3 to 5 days and the wound cleaned twice a day. While the wound is healing, horses should be fed in a position that does not require excessive stretching of the suture line
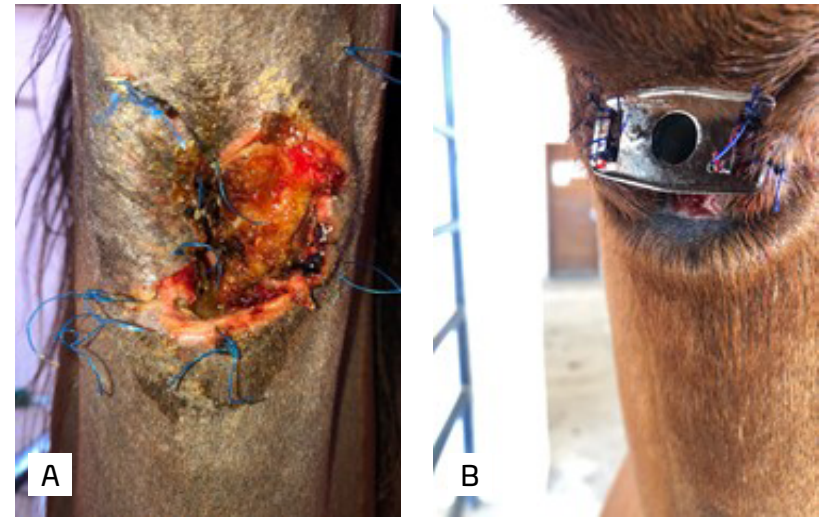

Figure 3. Placement of the tracheostomy cannula. B-Fixed tracheostomy cannula.

and be kept in a stall where no protruding objects allow rubbing of the surgical site. Once the wound heals, horses should not, under any circumstances, have the opportunity to swim.

After 36 days of hospitalization, the animal was discharged with clinical regression, the surgical wound was healed entirely, and there was no inflammation and/or infection. Carlier et al. (2016) reported that suture material could play an important role in surgical wound healing. The use of monofilament yarn assists in the perfect cosmetic result.

\section{CONCLUSION}

The animal presented stage IV laryngeal hemiplegia, a rare condition, and was submitted to tracheostomy and placement of a permanent tracheotomy due to its zootechnical value and the unavailability of resources to perform other techniques. This procedure proved efficient in regressing the clinical signs and consequently improved the patient's quality of life.

\section{REFERENCES}

AUER, J. A.; STICK, J. A.; KUMMERLE, J. M.; PRANGE, T. Flexural limb deformities. Equine Surgery. 5 ed., p. 1490-1509. 2019.

BYRNE, C. A.; BARAKZAI, S. Z. Equine emergency upper airway management. EquineVeterinaryEducation.v.32.n.6.p.325-334.2020.

CARLIER, S.; OOSTERLINCK, M.; MARTENS, A.; PILLE, F.Treatment of acquired flexural deformity of the distal interphalangeal joint in the horse: a retrospective study of 51 cases. Vlaams Diergeneeskundig Tijdschrift. v. 85. n. 1. p. 9-14. 2016.

CLERCQ, E.; ROSSICNOL, F; MARTENS. A. Laryngeal hemiplegia in the horse: an update. Vlaams Diergeneeskundig Tijdschrift. v. 87. п. 5. p. 283-294. 2018.

DAVENPORT-GOODALL, C. L. M.; PARENTE, E. J. Disorders of the larynix. Veterinary Clinics of North America: Equine Practice. v.19, n.l, p.169-187, 2003.
DIXON, P.; ROBINSON, E.; WADE, J. Workshop Summary. Proceddings of a Workshop on Equine Recurrent Laryngeal Neuropathy, Havemeyer Foundation Monograph Series No. 11 (p. 93-97). Stratford-upon-Avon, UK: R \& W Publications Ld. 2004.

GERBER, V. Genetics of equine respiratory disease. Veterinary Clinics of North America: Equine Practice. v. 36. n. 2. p. 243253. 2020.

LAWRENCE, R. J. BUTTERELL, M. J. CONSTABLE, J. D. DANIEL. Hold your horses: A comparison of human laryngomalacia with analogous equine airway pathology. International Journal of Pediatric Otorhinolaryngology. v. 105. p. 167-170. 2018.

MCCARREL, T. M.; WOODIE J.B. Update on laryngeal disorders and treatment. Veterinary Clinics Equine. v. 31, p. 13-26. 2015. 
RADOSTITS, O. M.; GAY, C. C.; BLOOD, D. C.; HINCHCLIFF, K. W. Clínica Veterinária: Um tratado de doenças dos bovinos, ovinos, suínos, caprinos e equinos. 9.ed. Rio de Janeiro: Guanabara Koogan, 2010. 1737p.

RONALDSON, H. L.; MONTICELLI, P.; SMITH, R.; ADAMI, C. Acute Life-threatening Laryngeal Dysfunction in a Draft Horse Recovering from General Anesthesia: A Case Report. Journal of Equine Veterinary Science. v. 91. P. 103-109. 2020.
SATOH, M.; HIGUCHI, T.; INOUE, S.; MIYAKOSHI, D.; KAJIHARA, A.; $\mathrm{COTOH,} \mathrm{T.;} \mathrm{SHIMIZU,} \mathrm{Y.} \mathrm{External} \mathrm{transcutaneous} \mathrm{ultrasound}$ technique in the equine cricoarytenoideus dorsalis muscle: Assessment of muscle size and echogenicity with resting endoscopy. Equine Veterinary Journal. v. 52. n. 4. p. 500508. 2020.

VALBERG, S.J. Genetics of Equine Muscle Disease. Veterinary Clinics of North America: Equine Practice. v. 36. n. 2. p. 353-378. 2020. 